\title{
Morphometric Analysis of the Foramen Magnum
}

\author{
Análisis Morfométrico del Foramen Magno \\ Osama A. Samara ${ }^{1}$; Justin Z. Amarin²; Darwish H. Badran ${ }^{3}$; Omar W. Al-Khayat ${ }^{1}$; \\ Haya H. Suradi²; Amjad T. Shatarat ${ }^{3}$ \& Maher T. Hadidi ${ }^{3}$
}

SAMARA, O. A.; AMARIN, J. Z.; BADRAN, D. H.; AL-KHAYAT, O. W.; SURADI, H. H.; SHATARAT, A. T. \& HADIDI, M. T. Morphometric analysis of the foramen magnum. Int. J. Morphol., 35(4):1270-1275, 2017.

SUMMARY: The foramen magnum is morphometrically typified by two perpendicular diameters and a distinct margin. This important anatomical landmark is subject to high interindividual variation. The objective of this study was to evaluate the dimensions and morphology of the foramen magnum in a Jordanian population. In this retrospective study, 247 individuals were consecutively sampled using the institutional picture archiving and communication system. The anteroposterior and transverse diameters of the foramen magnum were measured; the foramen magnum index was calculated; and, the shape of the foramen magnum was visually assessed. The sex-pooled anteroposterior and transverse diameters were $35.1 \pm 3.2 \mathrm{~mm}$ and $29.3 \pm 2.5 \mathrm{~mm}$, respectively. The sex-pooled foramen magnum index was $1.20 \pm 0.10$. The diameters were significantly different $(\mathrm{P}<0.001)$ and positively correlated $(\mathrm{r}=0.52, \mathrm{P}<0.001)$. Participant age was negatively correlated with the anteroposterior $\left(r_{s}=-0.15, P=0.02\right)$ and transverse $\left(r_{s}=-0.14, P=0.03\right)$ diameters. After controlling for participant age, there was a statistically significant difference in the anteroposterior diameter $(\mathrm{P}<0.001)$, the transverse diameter $(\mathrm{P}<0.001)$, and the foramen magnum index $(\mathrm{P}=0.02)$ between sexes. The foramen magnum was most commonly irregular in shape (36\% of all cases). In contrast to previous studies, we report, for the first time, a negative correlation between age and the diameters of the foramen magnum. In addition, a predominance of irregularly shaped foramen magnum was found. The finding makes an already heterogenous group of published data even more variable, prompting reconsideration of the role of visual assessment in morphometric studies.

KEY WORDS: Foramen magnum; Morphometry; Sexual dimorphism; Measurements; Morphology.

\section{INTRODUCTION}

The foramen magnum, Latin for "great opening", is an aperture in the occipital bone of the skull and the largest of the skull's foramina (Fig. 1). It transmits the continuation of the medulla oblongata as the spinal cord from the cranial cavity into the vertebral canal.

Numerous sources erroneously describe the foramen magnum as an oval opening; in fact, the morphology of the foramen magnum is subject to much variation. Two classification systems for the morphology of the foramen magnum and close variants thereof predominate the literature. The first classifies the foramen magnum as either: egg-shaped; round; oval; tetragonal; pentagonal; hexagonal; or, irregular (Murshed et al., 2003). The other, less common system classifies the foramen magnum into one of the following categories: circular; two semicircles; heart-like; wide oval; bi-rounded oval; ventrally wide oval; bi-pointed oval; or, dorsally convergent oval (Richards \& Jabbour, 2011).
The dimensions of the adult foramen magnum have been quantified in numerous studies (Burdan et al., 2014). It must be noted that the "adult" designation is rather arbitrary; the growth of the foramen magnum is mostly complete by age 4 years (Richards \& Jabbour). In addition, no ethnic or intergenerational variation in the morphometry of the foramen magnum has been reported (Gruber et al., 2009; Manoel et al., 2009).

The applications of morphometric analyses of the foramen magnum are quite diverse. For instance, the length and breadth of the foramen magnum is clinically relevant in patients with achondroplasia; the cervicomedullary junction may be compressed as a result of marked foramen magnum stenosis, resulting in neurologic manifestations (Ryken \& Menezes, 1994; Hecht et al., 2014). In addition, foramen magnum morphometry is relevant in forensic medicine. For example, sex determination based on foramen magnum

\footnotetext{
${ }^{1}$ Department of Radiology, School of Medicine, The University of Jordan, Queen Rania Al-Abdullah Street, Amman 11942, Jordan.

${ }^{2}$ School of Medicine, The University of Jordan, Queen Rania Al-Abdullah Street, Amman 11942, Jordan.

${ }^{3}$ Department of Anatomy and Histology, School of Medicine, The University of Jordan, Queen Rania Al-Abdullah Street, Amman 11942, Jordan.
} 


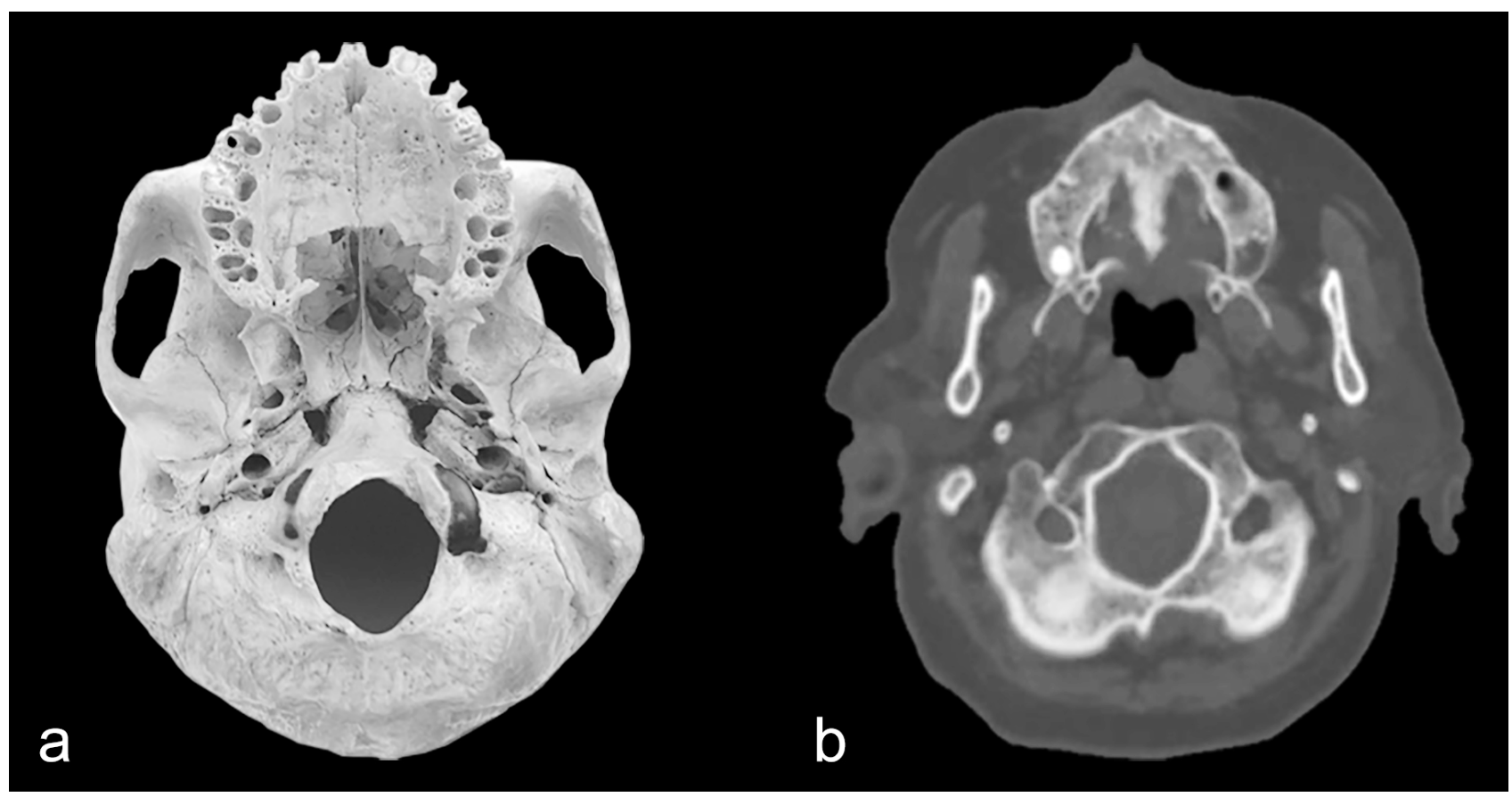

Fig. 1. Base of the skull. a. Gross anatomy. b. Radiography.

morphometry, albeit limited to some extent, is useful (Günay \& Altinkök, 2000; Suazo et al., 2009; Ukoha et al., 2011; Edwards et al., 2013; Kamath et al., 2015).

To the best of our knowledge, foramen magnum morphometry has only been studied in one Middle Eastern population (Uthman et al., 2012). Further documentation in more populations has been recommended (Erdil et al., 2010).

The aim of this study was to evaluate the dimensions and morphology of the foramen magnum in a Jordanian population.

\section{MATERIAL AND METHOD}

The study population in this Institutional Review Board (IRB)-approved (Jordan University Hospital, Amman, Jordan) retrospective study consisted of 247 individuals (125 males and 122 females; age range, 19-95 years; mean age, 57 years). Participants were consecutively sampled using the institutional picture archiving and communication system (PACS). To be considered for inclusion, participants had to have readily retrievable computed tomography images of the head, annotated age and sex data, and absence of focal brain lesions, atrophy, or other abnormalities of the central nervous system. Images were reviewed on a PACS workstation located in the Department of Radiology at the Jordan University Hospital.
Computed tomography images had been captured using a Siemens SOMATOM Definition. Continuous onemillimeter-thin slices were reviewed and an image depicting a well-defined foramen magnum was selected. The window width and window level were set at 2,000 and $400 \mathrm{HU}$, respectively. Measurements were made using the software's integrated ruler functionality (Synapse PACS, Fujifilm). The anteroposterior diameter was defined as the basion-opisthion distance. The transverse diameter was defined as the greatest distance between the lateral borders of the foramen magnum. The foramen magnum index was defined as the quotient of the anteroposterior and transverse diameters. The shape of the foramen magnum was determined by visual assessment. Age and sex were recorded last. No identifying information was collected.

Data were entered into the IBM SPSS Statistics Data Editor and subsequent analyses, based on $\mathrm{N}=247$ participants, were performed using this software package. A paired-samples t-test and a Pearson product-moment correlation were run between the anteroposterior and transverse diameters. An independent-samples t-test was run for age, with sex as the grouping variable. Spearman's rankorder correlation was run between participant age and the anteroposterior or transverse diameters. A one-way analysis of covariance (ANCOVA) was run three separate times using age as a covariate and sex as the independent variable. The dependent variable was either the anteroposterior diameter, the transverse diameter, or the foramen magnum index. All underlying assumptions were met. A P value $<0.05$ was 
considered to indicate a statistically significant difference. Numerical data are presented according to the recommendations of Cole (2015). Means are presented as mean \pm standard deviation $(\mathrm{SD})$, unless stated otherwise.

\section{RESULTS}

There was a statistically significant mean difference between the anteroposterior and transverse diameters $(\mathrm{P}<0.001)$. Additionally, a strong positive linear correlation was found between the two variables $(\mathrm{r}=0.52, \mathrm{P}<0.001)$. These relationships are represented in Figure 2.

There was no statistically significant difference in age between males and females $(\mathrm{P}=0.2)$. A weak negative linear correlation was found between participant age and the anteroposterior diameter $\left(\mathrm{r}_{\mathrm{s}}=-0.15, \mathrm{P}=0.02\right)$ as well as participant age and the transverse diameter $\left(r_{\mathrm{s}}=-0.14, \mathrm{P}=0.03\right)$. These relationships are visualized in Fig. 3 and Fig. 4.

After controlling for participant age, there was a statistically significant difference in the anteroposterior diameter $(\mathrm{P}<0.001)$, transverse diameter $(\mathrm{P}<0.001)$, and foramen magnum index $(\mathrm{P}=0.02)$ between males and females.

The mean sex-pooled anteroposterior and transverse diameters were $35.1 \pm 3.2$ and $29.3 \pm 2.5 \mathrm{~mm}$, respectively. The maximum and minimum sex-pooled anteroposterior

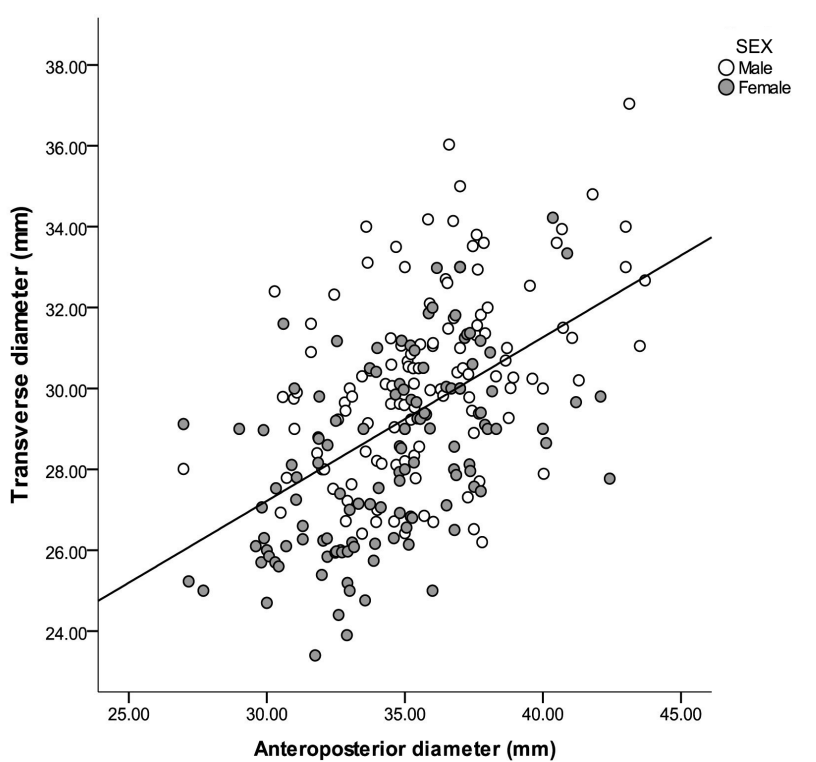

Fig. 2. The relationship between the anteroposterior and transverse diameters of the foramen magnum ( $\mathrm{N}=247$ participants). The line of best fit is shown as a solid line $(\mathrm{r}=0.52, \mathrm{P}<0.001)$.

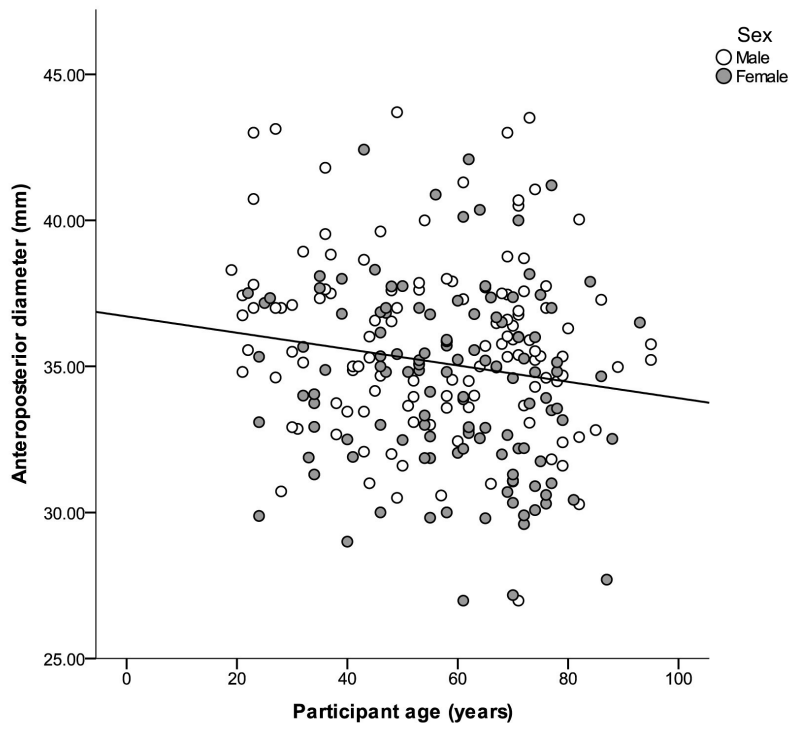

Fig. 3. The relationship between participant age and the anteroposterior diameter of the foramen magnum $(\mathrm{N}=247$ participants). The line of best fit is shown as a solid line ( $r_{\mathrm{s}}=-0.15$, $\mathrm{P}=0.02$ ).

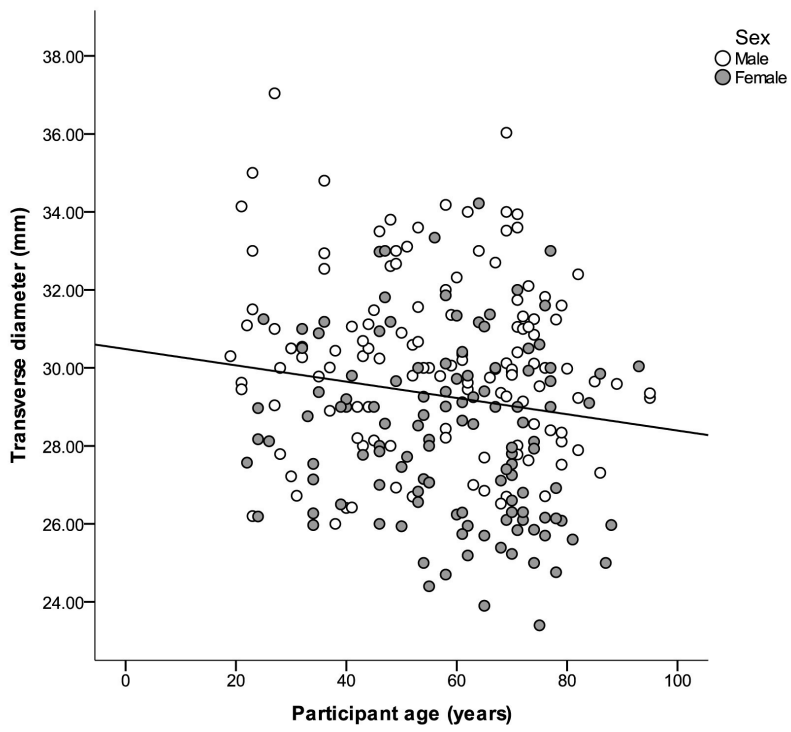

Fig. 4. The relationship between participant age and the transverse diameter of the foramen magnum ( $\mathrm{N}=247$ participants). The line of best fit is shown as a solid line $\left(\mathrm{r}_{\mathrm{s}}=-0.14, \mathrm{P}=0.03\right)$.

diameters ( 43.7 and $27.0 \mathrm{~mm}$, respectively) were greater than the maximum and minimum sex-pooled transverse diameters (37.0 and $23.4 \mathrm{~mm}$, respectively).

The mean and maximum anteroposterior diameters were greater in males ( $35.8 \pm 3.0$ and $43.7 \mathrm{~mm}$, respectively) than in females ( $34.4 \pm 3.1$ and $42.4 \mathrm{~mm}$, respectively). The minimum anteroposterior diameter was $27.0 \mathrm{~mm}$ in both sexes. The mean, maximum, and minimum transverse diameters were 
greater in males $(30.3 \pm 2.3,37.0$, and $26.0 \mathrm{~mm}$, respectively) than in females $(28.3 \pm 2.3,34.2$, and $23.4 \mathrm{~mm}$, respectively).

The mean, maximum, and minimum sex-pooled foramen magnum index were $1.20 \pm 0.10,1.53$, and 0.93 , respectively. The mean and maximum foramen magnum index were greater in females $(1.22 \pm 0.10$ and 1.53, respectively) than in males ( $1.19 \pm 0.10$ and 1.44 , respectively). The minimum foramen magnum index was 0.93 in both sexes. The descriptive statistics of the foramen magnum index are depicted in Figure 5.

The foramen magnum was irregularly shaped in 51 females $(42 \%)$ and 31 males (30\%)-occurring in greater frequency among participants of both sexes than any other shape. Oval- and egg-shaped foramen magnum were the next most common morphologies. An egg-shaped foramen magnum was documented in 22 females $(18 \%)$ and 34 males $(27 \%)$. An oval foramen magnum was documented in 28 females (23\%) and 22 males (18\%). In total, irregularly shaped (36\%), egg-shaped (23\%), and oval (20\%) foramen magnum were the most common morphologies, in that order. Morphological variants of the foramen magnum and their frequencies in the study population are listed in Table I.

Table I. Morphological variants of the foramen magnum and their frequencies in the study population.

\begin{tabular}{lccc}
\hline Shape & Male na & Female na & Total na \\
\hline Oval & $22(18 \%)$ & $28(23 \%)$ & $50(20 \%)$ \\
Round & $6(5 \%)$ & $2(2 \%)$ & $8(3 \%)$ \\
Egg & $34(27 \%)$ & $22(18 \%)$ & $56(23 \%)$ \\
Tetragonal & $16(13 \%)$ & $8(7 \%)$ & $24(10 \%)$ \\
Pentagonal & $7(6 \%)$ & $6(5 \%)$ & $13(5 \%)$ \\
Irregular & $37(30 \%)$ & $51(42 \%)$ & $88(36 \%)$ \\
Hexagonal & $3(2 \%)$ & $5(4 \%)$ & $8(3 \%)$ \\
\hline
\end{tabular}

${ }^{a}$ Absolute (relative) count of participants.

\section{DISCUSSION}

In regard to the diameters of the foramen magnum, we report values that are highly concordant with previous results (Burdan et al.). Of the two diameters, we found the anteroposterior diameter to be significantly greater in length $(\mathrm{P}<0.001)$. Indeed, the foramen magnum is traditionally recognized as a longitudinally elongated aperture. Nevertheless, exceptions may apply_ a round or transversely elongated foramen magnum was identified in eight cases.

Additionally, we found a strong positive linear correlation $(\mathrm{r}=0.52, \mathrm{P}<0.001)$ between the anteroposterior and transverse diameters, reflecting a proportionality in the rate of growth of the foramen magnum. This proportionality is highlighted by comparable foramen magnum indices in males and females $(1.19 \pm 0.10 \mathrm{~mm}$ and $1.22 \pm 0.10 \mathrm{~mm}$, respectively). Curiously, a sex-specific statistically significant difference $(\mathrm{P}=0.02)$ was found in the foramen magnum index; however, the finding does not appear to hold any practical importance.

The foramen magnum index may be strictly conserved across sociodemographic factors; the sex-pooled mean foramen magnum indices reported herein $(1.20 \pm 0.10$ $\mathrm{mm}$ ) and in a study by Chethan et al. (2012) are an exact match.

Interestingly, we found a weak negative linear correlation between the anteroposterior and transverse diameters of the foramen magnum and participant age $\left(r_{s}=-\right.$ $0.15, \mathrm{P}=0.02$ and $\mathrm{r}_{\mathrm{s}}=-0.14, \mathrm{P}=0.03$, respectively). To our knowledge, we are the first to report this type of correlation; other studies have reported either no correlation or a positive

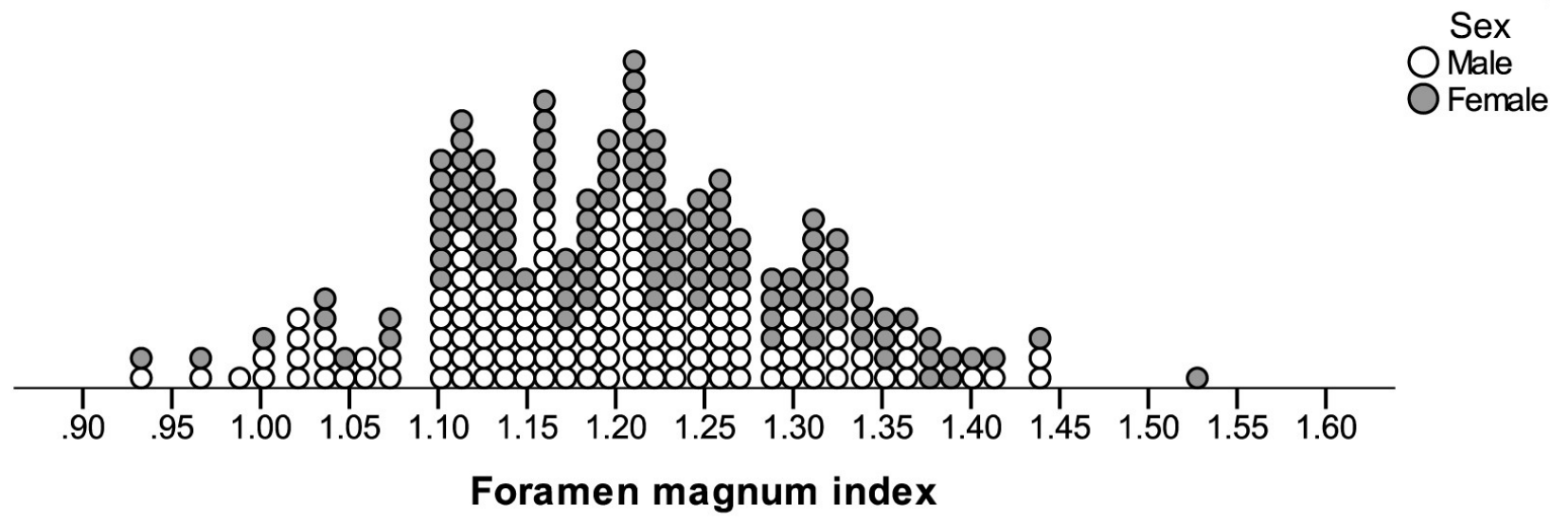

Fig. 5. Dot plot of the foramen magnum index ( $\mathrm{N}=247$ participants). 
correlation (Manoel et al.). Our combination of a large sample size $(\mathrm{N}=247)$ and a wide participant age range $(19$ to 95 years) may have been useful in unveiling an ageinduced change in the morphometry of the foramen magnum. Just as likely, this correlation may have been influenced by underlying sociodemographic and dietary factors; for instance, improved nutrition in recent decades-and an increase in stature, by extension - may have resulted in a regional intergenerational increase in the dimensions of the foramen magnum.

Sexual dimorphism of the foramen magnum was observed; the anteroposterior and transverse diameters were significantly greater in males than in females $(\mathrm{P}<0.001)$. Multiple studies have documented the sexual dimorphism of the foramen magnum (Günay \& Altinkök; Suazo et al.; Ukoha et al.; Edwards et al.; Kamath et al.). These studies have established no more than an adjunctive role for foramen magnum morphometry in sex determination. This finding, albeit interesting, appears to hold little translational value.

An irregularly shaped foramen magnum was present in $36 \%$ of all cases-more so than any other morphology. In three other studies, oval (64\%), round (22\%), or polygonal $(63 \%)$ foramen magnum were predominant (Zaidi \& Dayal, 1988; Murshed et al.; Poonamjeet et al., 2013). This gross heterogeneity may be attributable to ethnic variation; else, it may be the result of high interobserver variability. As visual assessment is an unreliable method, we are inclined toward the latter explanation.

Our study had several limitations. First, participant stature was not factored into the analysis. Therefore, the role of stature in the sexual dimorphism of the foramen magnum could not be determined. Detailed sociodemographic data could not be collected within the scope of the study. Further, the limitations associated with convenience sampling apply to the present study. Lastly, interobserver variability may represent a major source of error in regard to morphological assessment of the foramen magnum.

The results of the present study are generally consistent with the body of data currently available on foramen magnum morphometry. Ethnic variation, or lack thereof, is highlighted by this consistency. Our conclusions regarding the shape of the foramen magnum prompt further investigation into the validity and reliability of visual assessment in the context of foramen magnum morphology. To our knowledge, we report, for the first time, a negative linear correlation between age and the dimensions of the foramen magnum. The significance of this finding merits consideration in future investigations of foramen magnum morphometry.
SAMARA, O. A.; AMARIN, J. Z.; BADRAN, D. H.; ALKHAYAT, O. W.; SURADI, H. H.; SHATARAT, A. T. \& HADIDI, M. T. Análisis morfométrico del foramen magno. Int. J. Morphol., 35(4):1270-1275, 2017.

RESUMEN: El foramen magno está morfométricamente tipificado por dos diámetros perpendiculares y un margen. Este punto importante de referencia anatómica está sujeto a una alta variación interindividual. El objetivo del estudio fue evaluar las dimensiones y la morfología del foramen magno en una población jordana. En este estudio retrospectivo, 247 individuos fueron muestreados consecutivamente utilizando el sistema institucional y de comunicación de imágenes. Se midieron los diámetros anteroposterior y transversal del foramen magno; Se calculó el índice del foramen magno y se evaluó visualmente la forma dede éste. Los diámetros anteroposterior y transversal agrupados por sexo fueron $35,1 \pm 3,2 \mathrm{~mm}$ y $29,3 \pm 2,5 \mathrm{~mm}$, respectivamente. El índice del foramen magno, agrupado por sexo, fue $1,20 \pm 0,10$. Los diámetros fueron significativamente diferentes $(\mathrm{P}<0,001)$ y positivamente correlacionados $(r=0,52, \mathrm{P}<0,001)$. La edad de los participantes se correlacionó negativamente con los diámetros anteroposterior $\left(r_{s}=-0,15, P=0,02\right)$ y transversal $\left(r_{s}=-0,14, P=\right.$ 0,03 ). Después de verificar la edad de los participantes, hubo una diferencia estadísticamente significativa entre el diámetro anteroposterior $(\mathrm{P}<0,001)$, el diámetro transversal $(\mathrm{P}<0,001)$ y el foramen magno $(\mathrm{P}=0,02)$ entre ambos sexos. El foramen magno era más comúnmente de forma irregular (36\% de todos los casos). A diferencia de estudios anteriores, se informa por primera vez de una correlación negativa entre la edad y los diámetros del foramen magno. Además, se encontró un predominio de forámenes de forma irregular. El hallazgo indica que un grupo heterogéneo de datos ya publicados, sea aún más variable, lo que lleva a reconsiderar el papel de la evaluación visual en los estudios morfométricos.

PALABRAS CLAVE: Foramen magno; Morfometría; Dimorfismo sexual; Medidas; Morfología.

\section{REFERENCES}

Burdan, F.; Dworzanska, A.; Dworzanski, W.; Klepacz, R.; CendrowskaPinkosz, M.; Halasa, J.; Baka, J. \& Szumilo, J. Foramen Magnum - New and Old Anthropological Data. Glob. J. Anthropol. Res., 1:25-34, 2014.

Chethan, P.; Prakash, K. G.; Murlimanju, B. V.; Prashanth, K. U.; Prabhu, L. V.; Saralaya, V. V.; Krishnamurthy, A.; Somesh, M. S. \& Kumar, C. G. Morphological analysis and morphometry of the foramen magnum: an anatomical investigation. Turk. Neurosurg., 22(4):416-9, 2012.

Cole, T. J. Too many digits: the presentation of numerical data. Arch. Dis. Child., 100(7):608-9, 2015.

Edwards, K.; Viner, M. D.; Schweitzer, W. \& Thali, M. J. Sex determination from the foramen magnum. J. Forensic Radiol. Imaging, 1(4):186-92, 2013.

Erdil, F. H.; Sabancıgulları, V.; Çimen, M. \& Isik, O. Morphometric analysis of the foramen magnum by computed tomography. Erciyes Med. J., 32(3):167-70, 2010.

Gruber, P.; Henneberg, M.; Böni, T. \& Rühli, F. J. Variability of human foramen magnum size. Anat. Rec. (Hoboken), 292(11):1713-9, 2009.

Günay, Y. \& Altinkök, M. The value of the size of foramen magnum in sex determination. J. Clin. Forensic Med., 7(3):147-9, 2000. 
Hecht, J. T.; Bodensteiner, J. B. \& Butler, I. J. Neurologic manifestations of achondroplasia. Handb. Clin. Neurol., 119:551-63, 2014.

Kamath, V. G.; Asif, M.; Shetty, R. \& Avadhani, R. Binary logistic regression analysis of foramen magnum dimensions for sex determination. Anat. Res. Int., 2015:459428, 2015

Manoel, C.; Prado, F. B.; Caria, P. H. F. \& Groppo, F. C. Morphometric analysis of the foramen magnum in human skulls of brazilian individuals: its relation to gender. Braz. J. Morphol. Sci., 26(2):104-8, 2009.

Murshed, K. A.; Çiçekcibasi, A. E. \& Tuncer, I. Morphometric evaluation of the foramen magnum and variations in its shape: A study on computerized tomographic images of normal adults. Turk. J. Med. Sci., 33(5):301-6, 2003.

Poonamjeet, L.; Ongeti, K.; Pulei, A.; Ogengo, J. \& Mandela, P. Gender related patterns in the shape and dimensions of the foramen magnum in an adult Kenyan population. Anat. J. Afr., 2(2):138-41, 2013.

Richards, G. D. \& Jabbour, R. S. Foramen magnum ontogeny in Homo sapiens: a functional matrix perspective. Anat. Rec. (Hoboken), 294(2):199-216, 2011.

Ryken, T. C. \& Menezes, A. H. Cervicomedullary compression in achondroplasia. J. Neurosurg., 81(11):43-8, 1994.

Suazo, G. I. C.; Perez, R. P.; Zavando, M. D. A. \& Smith, R. L. Sexual dimorphism in the foramen magnum dimensions. Int. J. Morphol., 27(1):21-3, 2009.

Ukoha, U.; Egwu, O. A.; Okafor, I. J.; Anyabolu, A. E.; Ndukwe, G. U. \& Okpala, I. Sexual dimorphism in the foramen magnum of nigerian adult. Int. J. Biol. Med. Res., 2(4):878-81, 2011.

Uthman, A. T.; Al-Rawi, N. H. \& Al-Timimi, J. F. Evaluation of foramen magnum in gender determination using helical CT scanning. Dentomaxillofac. Radiol., 41(3):197-202, 2012.

Zaidi, S. H. \& Dayal, S. S. Variations in the shape of foramen magnum in Indian skulls. Anat. Anz., 167(4):338-40, 1988.

\author{
Corresponding author: \\ Dr. Osama A. Samara \\ Department of Radiology \\ School of Medicine \\ The University of Jordan \\ Queen Rania Al-Abdullah Street \\ Amman 11942 \\ JORDAN
}

\section{E-mail: osamara@ju.edu.jo}

Received: 20-03-2017

Accepted: 02-05-2017 